\title{
PENGARUH RELIGIUSITAS, PENDIDIKAN KELUARGA, DAN SOSIALISASI KEUANGAN TERHADAP LITERASI KEUANGAN SYARIAH DENGAN KECERDASAN INTELEKTUAL SEBAGAI VARIABEL MODERASI
}

\author{
Defa Defana Defiansih,Kardiyem \\ Universitas Negeri Semarang, Indonesia \\ ddefiansih@gmail.com
}

\begin{abstract}
Abstrak: Penelitian ini bertujuan menguji pengaruh religiusitas, pendidikan keluarga, dan sosialisasi keuangan terhadap literasi keuangan syariah dengan kecerdasan intelektual sebagai variabel moderasi. Penelitian ini menggunakan pendekatan kuantitatif. Populasi dalam penelitian ini adalah mahasiswa Pendidikan Ekonomi se-Kota Semarang Angkatan 2016 sejumlah 418 mahasiswa. Teknik pengambilan sampel manggunakan proportional stratified random sampling dengan jumlah sampel 204 mahasiswa berdasarkan rumus slovin tingkat kesalahan 5\%. Metode pengumpulan data menggunakan kuesioner. Teknik analisis data menggunakan analisis deskriptif dan analisis regresi moderasi dengan uji selisih mutlak. Hasil statistik deskriptif menunjukkan bahwa religiusitas berada pada kategori sangat tinggi, pendidikan keluarga pada katerogi baik, literasi keuangan syariah, sosialisasi keuangan, dan kecerdasan intelektual pada kategori tinggi. Hasil penelitian menunjukkan religiusitas berpengaruh positif dan signifikan terhadap literasi keuangan syariah, pendidikan keluarga tidak berpengaruh terhadap literasi keuangan syariah, dan sosialisasi keuangan berpengaruh positif dan signifikan terhadap literasi keuangan syariah. Kecerdasan intelektual hanya mampu memperkuat pengaruh sosialisasi keuangan terhadap literasi keuangan syariah.
\end{abstract}

Kata kunci: Kecerdasan Intelektual; Literasi Keuangan Syariah; Pendidikan Keluarga; Religiusitas; Sosialisasi Keuangan

\section{THE EFFECT OF RELIGIUSITY, FAMILY EDUCATION, AND FINANCIAL SOCIALIZATION ON SHARIA FINANCIAL LITERATION WITH INTELLECTUAL INTELLIGENCE AS MODERATION VARIABLES}

\begin{abstract}
The purpose of this study was to determine the effect of religiosity, family education, and financial socialization on Islamic financial literacy with intelligence quotient as a moderating variable. This study uses a quantitative approach. The population of this study is 418 students who study economics education in Semarang. Sampling techniques use proportional stratified random sampling to 204 students based on the Slovin formula error rate of $5 \%$. Data collection methods use questionnaires. Data analysis techniques use descriptive and regression analysis with absolute discrepancy. The descriptive study showed that Islamic financial literacy, religiosity, financial socialization, and intelligence quotient are higher, while family education is in a suitable category. The results showed that religiosity has a positive and significant impact on islamic financial literacy, familiy education does not affect islamic financial literacy, and financial socialization has a positive and significant effect on Islamic financial literacy. Intelligence quotient only strengthens the impact of financial socialization on Islamic financial literacy.
\end{abstract}

Keywords: Intellectual Intelligence; Sharia Financial Literacy; Family Education; Religiosity; Financial Dissemination

\section{PENDAHULUAN}

Rendahnya pengetahuan masya-rakat tentang industri keuangan beserta produk-produknya menyebabkan masya-rakat mudah terjebak dalam melakukan investasi yang cenderung menawarkan keuntungan menggiurkan tanpa memper-timbangkan risikonya yang akan didapat (Anita, Said 
Mohammad, 2014). Indonesia yang merupakan negara dengan penduduk muslim terbesar di dunia dengan jumlah sekitar 229 juta jiwa, seharusnya lebih mempertimbangkan dampak penggunaan produk keuangan yang non syariah dari pada negara lain sebab seluruh ulama sepakat jika riba dinyatakan haram dan termasuk dosa besar.

Indonesia berpotensi untuk menjadi salah satu pusat ekonomi syariah di tingkat regional maupun global. Pengembangan ekonomi dan keuangan syariah di Indonesia juga menjadi suatu komitmen bagi pemerintah. Salah satu bukti komitmen pemerintah tersebut yaitu dibentuknya Komite Nasional Keuangan Syariah (KNKS) yang ditetapkan melalui Peraturan Presiden (Perpres) Nomor 91 Tahun 2016 (Peraturan Presiden Tentang Komite Nasional Keuangan Syariah, 2016). KNKS bertugas mempercepat, memperluas, dan memajukan pengembangan keuangan syariah dalam rangka mendukung pembangunan ekonomi nasional. KNKS berpedoman pada Masterplan Arsitektur Keuangan Syariah Indonesia (MAKSI) dan Masterplan Ekonomi Syariah Indonesia (MEKSI).

Keberadaan KNKS, MAKSI, dan MEKSI berhasil memberikan dampak yang signifikan terhadap industri keuangan syariah di Indonesia. Berdasarkan laporan Islamic Finance Development Indicator (IFDI) tahun 2019 Indonesia berhasil mencapai peringkat keempat untuk pengembangan industri keuangan syariah dengan skor 68, padahal pada tahun 2018 Indonesia hanya meraih peringkat kesepuluh di dunia (Nurrahman, 2019). Peringkat Indonesia didukung oleh indikator Knowledge yang sub indikatornya yaitu jumlah riset keuangan syariah dan jumlah penyedia pendidikan keuangan syariah. Indonesia menempati urutan pertama dalam sub indikator penyedia pendidikan keuangan syariah terbanyak di dunia dengan jumlah 335. Indonesia juga menempati urutan kedua dalam sub indikator riset keuangan syariah dengan jumlah publikasi sebanyak 348. Detail rangking sub indikator pengembangan industri keuangan syariah dapat dilihat pada Gambar 1. Berikut:

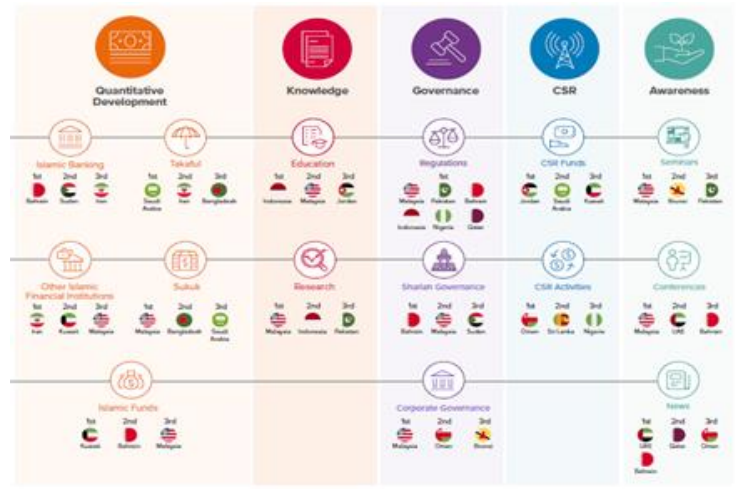

Gambar 1. Rangking Sub Indikator Pengembangan Indusri Keuangan Syariah

Berdasarkan data pada Gambar 1. Indonesia memang unggul dalam indikator Knowledge karena didukung oleh jumlah penyedia pendidikan keuangan syariah dan publikasi riset keuangan syariah, akan tetapi dalam indikator Quantitative Development, Governance, Corporate Soscial Responsibillity (CSR), dan Awareness Indonesia bahkan tidak masuk peringkat lima besar. Hal tersebut menunjukkan bahwa perkembangan industri keuangan syariah di Indonesia masih belum merata dalam setiap indikator. Indonesia harus terus meningkatkan pengembangan industri keuangan syariah pada indikatorindikator tersebut dengan memperkuat strategi dasar pengembangan ekonomi syariah. Empat strategi dasar untuk pengembangan ekonomi syariah adalah memperkuat (1) peraturan dan tata kelola; (2) kesadaran dan literasi publik; (3) penelitian dan pengembangan; (4) kualitas dan kuantitas sumber daya manusia (Islamic Corporation For The Development Of The Private Sector (ICD), 2019). Salah satu 
komponen kesadaran dan literasi publik yaitu literasi keuangan syariah. Literasi keuangan syariah dapat dipahami sebagai kombinasi pengetahuan, sikap, dan tingkah laku yang dibutuhkan terkait dengan pengambilan keputusan keuangan syariah (Karodoyo et al., 2018).

Literasi keuangan syariah menjadi dasar bagi masyarakat untuk memahami tentang produk dan layanan jasa keuangan syariah. Literasi keuangan syariah akan berdampak pada keputusan keuangan seseorang dalam memilih produk atau layanan jasa keuangan syariah sesuai dengan kebutuhan untuk meningkatkan kesejahteraan. Semakin tinggi literasi keuangan syariah seseorang, maka semakin tinggi pula tingkat pemanfaatan produk dan layanan jasa keuangan syariah. Hal tersebut akan membantu pengembangan industri keuangan syariah di Indonesia dari berbagai indikator. Faktanya, tingkat literasi keuangan syariah di Indonesia masih cukup rendah. Hasil Survei Nasional Literasi dan Inklusi Keuangan (SNLIK) yang dilakukan Otoritas Jasa Keuangan (OJK) tahun 2019 menunjukkan bahwa indeks literasi keuangan syariah di Indonesia sebesar 8,93\% dan hanya meningkat sebesar 0,93\% dari indeks literasi keuangan syariah pada tahun 2016.

Fenomena rendahnya tingkat literasi keuangan syariah juga terjadi di provinsi Jawa Tengah. Berdasarkan hasil SNLIK yang dilakukan OJK tahun 2016, tingkat literasi keuangan syariah di Jawa Tengah hanya mencapai angka $11,17 \%$, sedangkan tingkat literasi keuangan konvensional mampu mencapai angka 33,51\%. Hal ini menjadi suatu permasalahan yang harus diselesaikan oleh seluruh masyarakat Jawa Tengah, khususnya masyarakat yang tinggal di kawasan ibukota yaitu Kota Semarang karena lebih dekat dengan informasi, sarana, dan prasarana. Mahasiswa merupakan komponen masyarakat yang jumlahnya cukup besar dan berpengaruh terhadap perekonomian Indonesia karena mereka akan terjun langsung ke masyarakat setelah mereka lulus dari perguruan tinggi (Pujaningrum \& Nurkhin, 2018). Mahasiswa yang berada di kawasan Kota Semarang sangat berperan penting dalam peningkatan literasi keuangan syariah di Jawa Tengah, khususnya di Kota Semarang.

Peningkatan literasi keuangan syariah pada mahasiswa tidak terlepas dari peran perguruan tinggi. Universitas Institut Keguruan dan Ilmu Pendidikan Veteran (IVET) Semarang, Universitas Persatuan Guru Republik Indonesia (PGRI) Semarang, dan Universitas Negeri Semarang merupakan perguruan tinggi yang menyediakan Jurusan Pendidikan Ekonomi sekaligus menyediakan pendidikan keuangan syariah untuk mahasiswa Jurusan Pendidikan Ekonomi melalui mata kuliah ekonomi syariah. Universitas IVET Semarang dan Universitas PGRI Semarang memberikan mata kuliah ekonomi syariah pada mahasiswa Jurusan Pendidikan Ekonomi saat semester 6, sedangkan Universitas Negeri Semarang memberikan mata kuliah ekonomi syariah pada semester 3 atau 4.

Mahasiswa Jurusan Pendidikan Ekonomi dipersiapkan untuk menjadi pendidik yang profesional di bidang ekonomi, sehingga pengetahuan apapun terkait ekonomi harus dikuasai termasuk juga dengan pengetahuan mengenai ekonomi syariah. Lulusan Pendidikan Ekonomi akan sangat berperan dalam meningkatkan literasi keuangan syariah di Indonesia karena setelah lulus kemungkinan akan menjadi seorang guru, sehingga mempunyai kesempatan yang besar untuk mensosialisasikan literasi keuangan syariah kepada peserta didik melalui mata pelajaran ekonomi. Lulusan Pendidikan Ekonomi yang nantinya tidak menjadi seorang guru, akan tetap bisa mensosialisasikan dan menerapkan literasi keuangan syariah sesuai profesinya masing-masing. Harapannya mahasiswa Jurusan Pendidikan Ekonomi Universitas IVET Semarang, Universitas PGRI Semarang, dan Universitas Negeri Semarang memiliki tingkat literasi keuangan syariah yang paling tidak berada pada tingkat sufficient literate sebagai bekal untuk mendorong pertumbuhan ekonomi syariah di Indonesia khususnya di Jawa Tengah.

Hasil survei awal peneliti yang dilakukan pada tanggal 26 Januari sampai dengan 29 Januari 2019 pada 30 responden mahasiswa Jurusan Pendidikan Ekonomi se-Kota Semarang, menunjukkan hasil 
yang belum sesuai harapan. Hal ini dikarenakan persentase mahasiswa yang memiliki produk keuangan syariah, memahami tentang produk dan lembaga keuangan syariah, serta melibatkan prinsip syariah dalam pengelolaan keuangan pribadi masih cukup rendah. Pemahaman dan kepemilikan produk keuangan syariah responden masih terbatas pada produk perbankan syariah saja. Data hasil observasi awal peneliti dapat dilihat pada Tabel 1. berikut:

Tabel 1. Hasil Observasi Awal

\begin{tabular}{lcccc}
\hline \multicolumn{1}{c}{ Kategori } & \multicolumn{3}{c}{ Frekuensi } \\
\cline { 2 - 4 } & Ya & Tidak & Total \\
\hline $\begin{array}{l}\text { Melibatkan prinsip syariah } \\
\text { pengelolaan keuangan }\end{array}$ & dalam & & & \\
& & 13 & 30 \\
$\begin{array}{l}\text { Memilik produk keuangan syariah: } \\
\text { a. Tabungan syariah }\end{array}$ & 4 & 26 & 30 \\
$\begin{array}{l}\text { b. Asuransi syariah } \\
\text { c. Investasi syariah }\end{array}$ & 1 & 29 & 30 \\
& 1 & 29 & 30
\end{tabular}

Memahami produk dan akad pada lembaga keuangan:

\begin{tabular}{lccc} 
a. Perbankan syariah & 18 & 12 & 30 \\
b. Perasuransian syariah & 8 & 22 & 30 \\
c. Pasar modal syariah & 8 & 22 & 30 \\
\hline
\end{tabular}

Sumber: Data observasi awal Mahasiswa Pendidikan Ekonomi se-Kota Semarang angkatan 2016.

Berdasarkan Tabel 1. hanya 4 responden yang memiliki tabungan syariah dan 1 responden yang memiliki produk asuransi dan investasi syariah. Alasan responden belum menggunakan produk keuangan syariah sebagian besar karena belum memahami akad pada produk keuangan syariah, sudah terbiasa dengan produk keuangan konvensional, dan berasumsi bahwa prosedur yang ada pada produk keuangan syariah sama saja dengan prosedur pada produk keuangan konvensional. Hasil survei tersebut hanya mengukur tingkat literasi keuangan syariah pada sebagian kecil mahasiswa saja, sehingga untuk mengetahui tingkat literasi keuangan syariah mahasiswa Jurusan Pendidikan Ekonomi se-Kota Semarang perlu dilakukan kajian yang lebih mendalam.

Kajian mengenai literasi keuangan syariah merupakan kajian yang berkaitan dengan aspek kognitif, sehingga erat kaitannya dengan teori kognitif sosial yang dikembangkan oleh (Anastasi, A., \& Urbina, 2013). Bandura dalam Santrock (2009:323) mengembangkan sebuah kerangka timbal balik yang terdiri atas tiga faktor utama yaitu perilaku, lingkungan, dan orang/kognitif. Bandura dalam Schunk (2012:165) mengatakan istilah "timbal balik" untuk mengindikasikan adanya interaksi dari dorongandorongan, tidak hanya suatu tindakan yang sama. Adapun gambar skema teori kognitif sosial sebagai berikut:

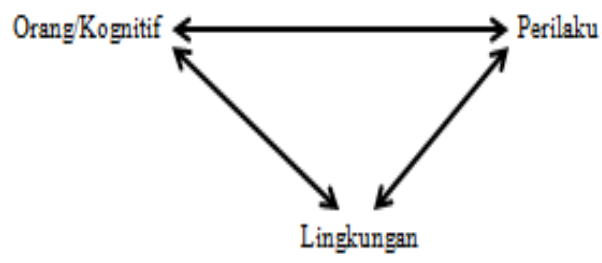

Gambar 2. Model Kuasalitas Timbal Balik Tiga Sisi oleh Bandura Sumber: Schunk (2012:165) 
Menurut pendapat Bandura dalam Schunk (2012:163) keberhasilan proses belajar sosial seseorang sangat dipengaruhi oleh tiga hal yang saling berhubungan yaitu proses belajar sosial itu sendiri, faktorfaktor kognitif, dan behavioral. Pemahaman dan perilaku mengenai literasi keuangan syariah tidak terlepas dari proses belajar sosial atau faktor eksternal dan faktor-faktor kognitif atau faktor internal.

Religiusitas merupakan salah satu faktor internal yang dapat mempengaruhi tingkat literasi keuangan syariah seseorang. Religiusitas merupakan faktor internal dalam diri seseorang berupa keyakinan kepada Allah SWT yang keberadaannya dapat mempengaruhi perilaku seseorang untuk menjalankan atau meninggalkan sesuatu sesuai dengan aturan syariat. Religiusitas dapat dilihat dari aktivitas beragama dalam kehidupan sehari-hari yang dilaksanakan secara rutin dan konsisten. Semakin sering seseorang terlibat dalam aktivitas beragama, maka diharapkan semakin tinggi tingkat religiusitasnya dan semakin besar pula dorongan untuk mempelajari dan mengamalkan ajaran agama dalam hal keuangan salah satunya yaitu literasi keuangan syariah.

Hasil penelitian Rahim et al., (2016) menemukan bahwa religiusitas berpengaruh positif dan signifikan terhadap literasi keuangan syariah sebesar 92\%. Sejalan dengan penelitian tersebut, hasil penelitian (Meiati \& Jayanto, 2019) juga menemukan bahwa religiusitas dapat mempengaruhi tingkat literasi keuangan syariah seseorang, akan tetapi persentase pengaruh yang ditemukan masih berada dibawah 50\% yaitu sebesar 33\%. Penemuan tersebut berbeda pula dengan hasil penelitian Wibowo \& Nurkhin (2018) dan Eliza (2018) yang menemukan bahwa religiusitas tidak berpengaruh terhadap literasi keuangan syariah.

Salah satu faktor eksternal yang dapat mempengaruhi literasi keuangan syariah adalah pendidikan. Pendidikan sangat berperan penting dalam pembentukan literasi keuangan syariah baik pendidikan informal di lingkungan keluarga melalui orang tua, maupun pendidikan formal di lingkungan perguruan tinggi melalui pemberian mata kuliah keuangan syariah seperti ekonomi syariah. Pendidikan keuangan di keluarga yang diberikan orang tua akan mempengaruhi tingkat literasi keuangan syariah seseorang. Apabila dalam lingkungan keluarga orang tua sudah memberikan bekal berupa wawasan mengenai keuangan syariah atau menanamkan pola hidup yang berdasarkan pada prinsip syariah, maka hal tersebut akan mempengaruhi pembentukan literasi keuangan syariah seorang mahasiswa.

Penelitian literasi keuangan syariah yang melibatkan variabel pendidikan keluarga pernah dilakukan oleh Fitriani (2017) dengan hasil pendidikan pengelolaan keuangan keluarga berpengaruh positif terhadap literasi keuangan, tetapi hanya sebesar 17\%. Wibowo \& Nurkhin (2018) juga melakukan penelitian tentang literasi keuangan syariah dengan menggunakan variabel pendidikan keluarga, namun pengaruh positif signifikan yang ditemukan sebesar 53\%. Berbeda dengan hasil penelitian Wibowo \& Nurkhin (2018) dan Fitriani (2017), penelitian Lutfi (2018) menemukan hasil bahwa pendidikan keluarga tidak berpengaruh signifikan terhadap literasi keuangan syariah.

Faktor eksternal berikutnya yang memiliki potensi dalam meningkatkan pengetahuan keuangan dan menstimulasi literasi keuangan individu adalah sosialisasi keuangan (Maria, 2019). Sosialisasi keuangan yang pengaruhnya terus tumbuh dan semakin kuat adalah teman sebaya dan media. Semakin seseorang berkembang, maka akan semakin banyak mengenal dan bersosialisasi sehingga dapat menambah wawasan seseorang. Pengetahuan mengenai keuangan syariah bisa didapatkan dengan mengikuti sosialisasi keuangan syariah seperti kegiatan seminar, berdiskusi dengan teman sebaya, atau mengumpulkan informasi melalui media. Sosialisasi keuangan merefleksikan pengetahuan keuangan syariah yang didapatkan mahasiswa sehingga mendorong tingkat literasi keuangan syariah yang dimiliki. 
Dewanty \& Isbanah (2018) menemukan bahwa sosialisasi keuangan memiliki pengaruh positif dan signifikan terhadap literasi keuangan yaitu sebesar $72,4 \%$. Penelitian dengan variabel serupa juga dilakukan oleh (Maria (2019), akan tetapi pengaruh yang ditemukan hanya sebesar yaitu 15,8\%. Berbeda dengan kedua penelitian tersebut, Widarni \& Chairil (2019) menemukan bahwa sosialisasi keuangan tidak berpengaruh terhadap literasi keuangan.

Berdasarkan inkonsistensi hasil beserta perbedaan kuat lemahnya pengaruh variabel independen terhadap variabel dependen pada penelitian terdahulu, maka peneliti menghadirkan variabel moderasi sebagai solusi. Variabel moderasi yang digunakan yaitu kecerdasan intelektual. Anastasi \& Urbina (2007:325) menyatakan bahwa kecerdasan intelektual adalah ekspresi dari tingkat kemampuan individu pada saat tertentu dalam hubungan dengan norma usia yang ada. Kecerdasan intelektual digunakan untuk melihat kemampuan seseorang dalam memecahkan masalah. Kecerdasan intelektual juga berhubungan dengan informasi yang diterima. Seseorang dikatakan cerdas apabila memiliki daya ingat yang baik, yaitu menggabungkan informasi baru dengan informasi yang sudah ada, pandai menyederhanakan, mencerna, menguasai, dan menggunakan informasi untuk menemukan pemecahan suatu masalah (Setiawati, 2016).

Beberapa penelitian terdahulu juga menjadi dasar pertimbangan pemilihan variabel kecerdasan intelektual. Penelitian Setiawati (2016) menemukan bahwa kecerdasan intelektual berpengaruh positif signifikan terhadap literasi keuangan. Sejalan dengan penelitian tersebut, hasil penelitian yang dilakukan Herd et al., (2012) menyatakan bahwa tinggi rendah kecerdasan intelektual mempunyai pengaruh yang positif signifikan terhadap literasi keuangan. Kedua penelitian tersebut menjelaskan bahwa seseorang dengan kecerdasan intelektual yang baik akan mampu menyelesaikan masalah keuangan, sehingga akan memiliki literasi keuangan yang baik pula. Tingkat kecerdasan intelektual yang dimiliki seseorang akan menentukan kemampuannya dalam mengingat, menghitung, mengarahkan perilaku, dan memecahkan masalah. Kemampuan-kemampuan tersebut akan mampu memperkuat pengaruh religiusitas, pendidikan keluarga, dan sosialisasi keuangan terhadap literasi keuangan syariah.

\section{METODE}

Jenis penelitian ini merupakan penelitian eksplanatif asosiatif dengan pendekatan kuantitatif prediksi. Data dalam penelitian ini menggunakan sumber primer dengan teknik pengumpulan data melalui kuesioner. Populasi dalam penelitian ini adalah mahasiswa Jurusan Pendidikan Ekonomi se-Kota Semarang Angkatan 2016 yang berjumlah 418 mahasiswa. Jumlah sampel sebanyak 204 mahasiswa dihitung menggunakan rumus Slovin dengan tingkat kesalahan $5 \%$. Teknik pengambilan sampel dalam penelitian ini yaitu menggunakan proportional random sampling. Sampel yang dipilih yaitu mahasiswa Pendidikan Ekonomi se-Kota Semarang Angkatan 2016 yang beragama Islam karena keuangan syariah pada umumnya lebih dikhususkan untuk umat muslim atau yang beragama Islam.

Variabel yang digunakan dalam penelitian ini yaitu literasi keuangan syariah (Y) sebagai variabel dependen. Religiusitas (X1), pendidikan keluarga (X2), dan sosialisasi keuangan (X3) sebagai variabel independen, serta kecerdasan intelektual $(Z)$ sebagai variabel moderasi.

Variabel literasi keuangan syariah $(\mathrm{Y})$ diukur berdasarkan 5 indikator menurut Otoritas Jasa Keuangan (OJK) dalam Survei Nasional Literasi dan Inklusi Keuangan Indonesia (SNLIK) 2016 yaitu 1) pengetahuan keuangan; 2) keterampilan keuangan; 3) keyakinan pada lembaga, jasa dan produk keuangan; 4) sikap keuangan; 5) perilaku keuangan. Variabel religiusitas (X1) diukur berdasarkan pendapat (Djamaludin Ancok, 2015) dengan 5 indikator yaitu 1) dimensi keyakinan; 2) dimensi praktik agama; 3) dimensi pengalaman; 4) dimensi pengetahuan agama; 5) dimensi pengamalan atau konsekuensi. Variabel pendidikan keluarga (X2) diukur menggunakan 6 indikator menurut (Slameto, 
2010) yaitu 1) cara orang tua mendidik; 2) relasi antar anggota keluarga; 3) suasana rumah; 4) keadaan ekonomi keluarga; 5) sikap pengertian orang tua; 6) latar belakang orang tua. Variabel sosialisasi keuangan (X3) diukur menggunakan 2 indikator menurut (Ahmad Sabri, 2005) yaitu teman sebaya dan media. Variabel kecerdasan intelektual $(Z)$ diukur berdasarkan pendapat Ode (2011) dengan 5 indikator yaitu 1) kemahiran dalam berhitung; 2) pemahaman verbal; 3) pemahaman visualisasi ruang; 4) kemampuan dalam memecahkan masalah; 5) kemampuan dalam ingatan.

Teknik analisis data menggunakan analisis statistik deskriptif dan uji selisih nilai mutlak untuk mengetahui pengaruh interaksi variabel independen terhadap literasi keuangan syariah pada Mahasiswa Pendidikan Ekonomi Universitas Negeri Semarang angkatan 2016 dengan kecerdasan intelektual sebagai variabel moderasi. Model penelitian ini dapat dilihat pada Gambar 3. berikut:

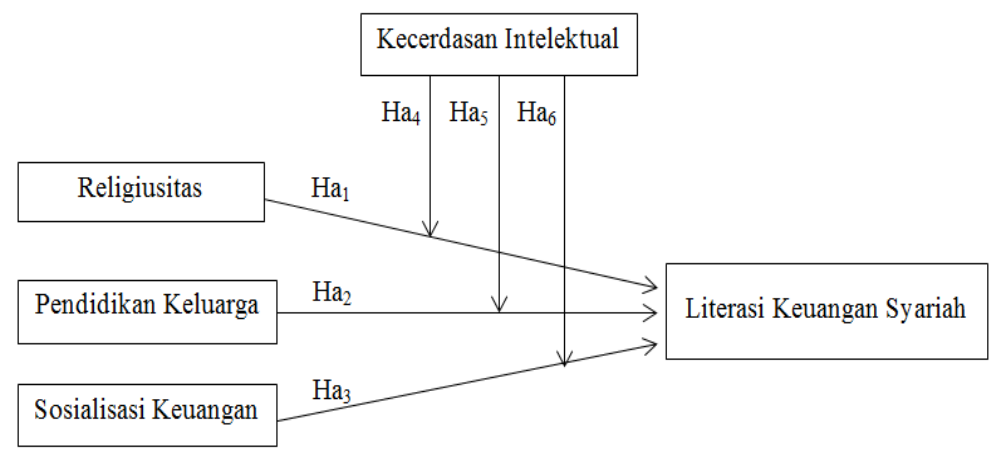

Gambar 3. Model Kerangka Berpikir

\section{HASIL DAN PEMBAHASAN}

Hasil analisis statistik deskriptif menunjukkan bahwa literasi keuangan syariah pada Mahasiswa Pendidikan Ekonomi Universitas Negeri Semarang angkatan 2016 dalam kategori tinggi. Berikut tabel ringkasan hasil analisis statistik deskriptif dari masing-masing variabel penelitian.

Tabel 2. Analisis Deskriptif Variabel

\begin{tabular}{llllll}
\hline Variabel & Min & Maks & Mean & Std. Dev & Kategori \\
\hline Literasi Keuangan Syariah & 39 & 110 & 84,36 & 10,307 & Tinggi \\
Religiusitas & 23 & 85 & 72,59 & 8,438 & Tinggi \\
Pendidikan Keluarga & 31 & 90 & 65,78 & 10,546 & Baik \\
Sosialisasi Keuangan & 11 & 50 & 36,16 & 6,541 & Tinggi \\
Kecerdasan Intelektual & 26 & 75 & 55,98 & 8,629 & Tinggi \\
\hline
\end{tabular}

Sumber:Hasil Olah Data, 2020.

Tabel 2 menunjukkan bahwa variabel literasi keuangan syariah, variabel religiusitas, variabel sosialisasi keuangan, dan variabel kecerdasan intelektual berada dalam kategori tinggi, sedangkan variabel pendidikan keluarga dalam kategori baik. Analisis statistik deskriptif memberikan gambaran atau deskripsi data secara individual dengan melihat distribusi data yang diperoleh dari jawaban responden meliputi nilai terendah, nilai tertinggi, dan nilai rata-rata. Pada variabel literasi keuangan syariah diperoleh nilai tertinggi 110 dan nilai terendah 39 dengan standar deviasi sebesar 10,307. Ratarata nilai untuk variabel lieterasi keuangan syariah adalah 84,36 yang termasuk dalam kategori tinggi. Diketahui dari 204 responden mahasiswa Pendidikan Ekonomi Universitas se-Kota Semarang angkatan 2016 yang memiliki literasi keuangan syariah sangat tinggi sejumlah 35 mahasiswa atau 
$17,16 \%$, literasi keuangan syariah dengan kategori tinggi sejumlah 144 mahasiswa atau 70,59\%, literasi keuangan syariah kategori cukup sejumlah 23 mahasiswa atau 11,27\%, literasi keuangan syariah kategori rendah sejumlah 0 mahasiswa atau $00,00 \%$, dan literasi keuangan syariah kategori sangat rendah sejumlah 2 mahasiswa atau 0,98\%.

Pada variabel religiusitas diperoleh nilai tertinggi 85 dan nilai terendah 23 dengan standar deviasi sebesar 8,438. Rata-rata nilai untuk variabel religiusitas adalah 72,59 yang termasuk dalam kategori sangat tinggi. Diketahui dari 204 responden mahasiswa Pendidikan Ekonomi Universitas se-Kota Semarang angkatan 2016 yang memiliki religiusitas sangat tinggi sejumlah 102 mahasiswa atau 50,00\%, religiusitas dengan kategori tinggi sejumlah 96 mahasiswa atau 47,06\%, religiusitas kategori cukup sejumlah 3 mahasiswa atau 1,47\%, religiusitas kategori rendah sejumlah 2 mahasiswa atau 0,98\%, dan religiusitas kategori sangat rendah sejumlah 1 mahasiswa atau 0,49\%.

Pada variabel pendidikan keluarga diperoleh nilai tertinggi 90 dan nilai terendah 31 dengan standar deviasi sebesar 10,546. Rata-rata nilai untuk variabel pendidikan keluarga adalah 65,78 yang termasuk dalam kategori baik. Diketahui dari 204 responden mahasiswa Pendidikan Ekonomi Universitas seKota Semarang angkatan 2016 yang memiliki pendidikan keluarga sangat baik sejumlah 23 mahasiswa atau $11,76 \%$, pendidikan keluarga dengan kategori baik sejumlah 106 mahasiswa atau 51,96\%, pendidikan keluarga kategori cukup sejumlah 67 mahasiswa atau 32,84\%, pendidikan keluarga kategori buruk sejumlah 6 mahasiswa atau 2,94\%, dan pendidikan keluarga kategori sangat buruk sejumlah 1 mahasiswa atau $0,49 \%$.

Pada variabel sosialisasi keuangan diperoleh nilai tertinggi 50 dan nilai terendah 11 dengan standar deviasi sebesar 6,541. Rata-rata nilai untuk variabel sosialisasi keuangan adalah 36,16 yang termasuk dalam kategori tinggi. Diketahui dari 204 responden mahasiswa Pendidikan Ekonomi Universitas seKota Semarang angkatan 2016 yang memiliki sosialisasi keuangan sangat tinggi sejumlah 30 mahasiswa atau 14,78\%, sosialisasi keuangan dengan kategori tinggi sejumlah 114 mahasiswa atau $56,16 \%$, sosialisasi keuangan kategori cukup sejumlah 49 mahasiswa atau $24,14 \%$, sosialisasi keuangan kategori rendah sejumlah 5 mahasiswa atau 2,46\%, dan sosialisasi keuangan kategori sangat rendah sejumlah 5 mahasiswa atau 2,46\%.

Pada variabel kecerdasan intelektual diperoleh nilai tertinggi 75 dan nilai terendah 26 dengan standar deviasi sebesar 8,629. Rata-rata nilai untuk variabel kecerdasan intelektual adalah 55,98 yang termasuk dalam kategori tinggi. Diketahui dari 204 responden mahasiswa Pendidikan Ekonomi Universitas se-Kota Semarang angkatan 2016 yang memiliki kecerdasan intelektual sangat tinggi sejumlah 33 mahasiswa atau 16,18\%, kecerdasan intelektual dengan kategori tinggi sejumlah 127 mahasiswa atau 62,25\%, kecerdasan intelektual kategori cukup sejumlah 37 mahasiswa atau 18,14\%, kecerdasan intelektual kategori rendah sejumlah 6 mahasiswa atau 2,94\%, dan kecerdasan intelektual kategori sangat rendah sejumlah 1 mahasiswa atau 0,49\%.

Analisis selanjutnya menggunakan hasil uji selisih nilai mutlak, namun sebelum melakukan uji selisih nilai mutlak terlebih dahulu melakukan uji prasyarat dan uji asumsi klasik. Uji prasyarat terdiri dari uji normalitas dan uji lienaritas. Adapun hasil uji normalitas dengan uji One Sample KolmogrovSmirnov diperoleh nilai Asymp. Sig dengan literasi keuangan syariah sebagai variabel dependen sebesar 0,449>0,05 yang berarti bahwa data pada penelitian ini dapat dikatakan berdistribusi normal. Uji selanjutnya yaitu uji linearitas menggunakan uji Durbin-Watson $(D-W)$ dengan ketentuan nilai $\mathrm{D}$-W > d1. Nilai D-W sebesar 1,855. Nilai tersebut lebih besar jika dibandingkan dengan nilai dl dengan $\mathrm{n}=$ 204 dan $\mathrm{k}=4$ yaitu $\mathrm{dl}=1,810$. Hasil tersebut menunjukkan bahwa spesifikasi model persamaan yang digunakan memiliki hubungan yang linier.

Uji asumsi klasik terdiri dari uji multikolinearitas dan uji heteroskedastisitas. Uji multikolonearitas dapat diketahui dengan melihat nilai Tolorance dan Variabel Inflation Factor (VIF). 
Tabel 3. Hasil Uji Multikolonearitas

\begin{tabular}{lccc}
\hline \multirow{2}{*}{ Variabel } & \multicolumn{2}{c}{ Uji Multikolonearitas } & Uji Heteroskedastisitas \\
\cline { 2 - 4 } & Tolerance & VIF & Rank Spearman Sig. \\
\hline R & 0,753 & 1,327 & 0,148 \\
PK & 0,656 & 1,525 & 0,895 \\
SK & 0,561 & 1,784 & 0,938 \\
KI & 0,521 & 1,921 & 0,959 \\
\hline
\end{tabular}

Masing-masing variabel yaitu Religiusitas (R), Pendidikan Keluarga (PK), Sosialisasi Keuangan (SK), dan Kecerdasan Intelektual (KI) memiliki nilai tolerance $>0,10$ dan nilai VIF $<10$, sehingga dapat disimpulkan bahwa masing-masing variabel independen yang digunakan dalam penelitian ini tidak terjadi multikolonearitas. Uji asumsi klasik berikutnya yaitu uji heteroskedastisitas. Pengujian gejala heteroskedastisitas dalam penelitian ini dilakukan menggunakan uji koefisien korelasi Rank Spearman dengan melihat nilai signifikansi. Hasil uji heteroskedastisitas menunjukkan bahwa variabel religiusitas $(0,148>0,05)$, pendidikan keluarga $(0,895>0,05)$, sosialisasi keuangan $(0,938>0,05)$ dan variabel kecerdasan intelektual $(0,959>0,05)$ mempunyai nilai signifikansi $>0,05$ sehingga dapat disimpulkan bahwa pada model regresi tidak terdapat heteroskedastisitas.

Uji selanjutnya yaitu uji selisih nilai mutlak yang dilakukan untuk mengetahui pengaruh interaksi antara variabel moderasi dengan variabel independen terhadap variabel dependen. Adapun hasil uji selisih nilai mutlak per variabel adalah sebagai berikut:

Tabel 4. Hasil Uji Selisih Nilai Mutlak

\begin{tabular}{lcc}
\hline Hipotesis & Koefisien & Sig \\
\hline Constant & 85,661 & 0,000 \\
Zscore(R) & 3,260 & 0,000 \\
Zscore(PK) &, 815 & 0,206 \\
Zscore(SK) & 3,602 & 0,000 \\
R_KI & $-2,910$ & 0,001 \\
PK_KI & $-1,126$ & 0,176 \\
SK_KI & 3,318 & 0,001 \\
\hline
\end{tabular}

Hasil uji selisih nilai mutlak pada Tabel 11 menunjukkan nilai konstanta sebesar 85,661. Religiusitas memiliki koefisien regresi sebesar 3,260. Pendidikan keluarga memiliki koefisien 0,815. Sosialisasi keuangan memiliki koefisien 3,602. Masing-masing koefisien regresi dari nilai selisih mutlak antara variabel independen dan variabel moderasi yaitu kecerdasan intelektual berturut-turut sebesar 2,910, -1,126, dan 3,318, sehingga diperoleh model regresi sebagai berikut:

\section{$\mathrm{LKS}=85,661+3,260 \mathrm{R}+$ 0,815PK + 3,602SK 2,910R_KI - 1,126PK_KI + 3,318SK_KI + e}

Persamaan regresi moderasi di atas dapat diartikan bahwa Konstanta sebesar 85,661 memiliki arti bahwa ketika variabel bebas bernilai nol (0), maka literasi keuangan syariah mahasiswa Pendidikan Ekonomi se-Kota Semarang Angkatan 2016 bernilai 85,661.

Peneliti juga melakukan uji koefisien determinasi secara parsial. Uji koefisien determinasi parsial $\left(\mathrm{r}^{2}\right)$ dilakukan untuk mengetahui kontribusi masing-masing variabel independen dalam menjelaskan variabel dependen. Berikut Tabel hasil uji koefisien determinasi parsial: 
Tabel 5. Uji Koefisien Determinasi Parsial $\left(\mathrm{r}^{2}\right)$

\begin{tabular}{lccc}
\hline Model & Zero-order & Partial & Part \\
\hline Zscore(R) & 0,554 & 0,354 & 0,269 \\
Zscore(PK) & 0,443 & 0,090 & 0,064 \\
Zscore(SK) & 0,496 & 0,362 & 0,276 \\
R_KI & $-0,385$ & $-0,242$ & $-0,178$ \\
PK_KI & $-0,178$ & $-0,096$ & $-0,069$ \\
SK_KI & 0,106 & 0,242 & 0,178 \\
\hline
\end{tabular}

Berdasarkan Tabel 5. dapat diketahui bahwa variabel religiusitas memiliki nilai correlations partial sebesar 0,354 . Nilai tersebut kemudian dikuadratkan $\left(0,354^{2}\right)=0,1253$ dan dipersentasekan $(0,1253 \mathrm{x}$ $100 \%)=12,53 \%$. Secara parsial,variabel religiusitas mempengaruhi literasi keuangan syariah sebesar 0,1253 atau $12,53 \%$. Variabel pendidikan keluarga memiliki nilai correlations partial sebesar 0,090 . Nilai tersebut kemudian dikuadratkan $\left(0,090^{2}\right)=0,0081$ dan dipersentasekan $(0,0081 \times 100 \%)=0,81 \%$. Secara parsial, variabel pendidikan keluarga mempengaruhi literasi keuangan syariah sebesar 0,0081 atau $0,81 \%$. Variabel sosialisasi keuangan memiliki nilai correlations partial sebesar 0,362. Nilai tersebut kemudian dikuadratkan $\left(0,362^{2}\right)=0,1310$ dan dipersentasekan $(0,1310 \times 100 \%)=13,10 \%$. Secara parsial, variabel sosialisasi keuangan mempengaruhi literasi keuangan syariah sebesar 0,1310 atau $13,10 \%$.

Selisih mutlak variabel religiusitas dan kecerdasan intelektual memiliki nilai correlations partial sebesar $-0,242$. Nilai tersebut dikuadratkan $\left(-0,242^{2}\right)=0,058$ dan dipersentasekan $(0,058 \times 100 \%)=$ $5,85 \%$. Secara parsial, interaksi variabel religiusitas dengan kecerdasan intelektual mempengaruhi literasi keuangan syariah sebesar 0,058 atau $5,85 \%$. Selisih mutlak variabel pendidikan keluarga dan kecerdasan intelektual memiliki nilai correlations partial sebesar $-0,096$. Nilai tersebut kemudian dikuadratkan $\left(-0,096^{2}\right)=0,0092$ dan dipersentasekan $(0,092 \times 100 \%)=0,92 \%$. Secara parsial, interaksi variabel pendidikan keluarga dengan kecerdasan intelektual mempengaruhi literasi keuangan syariah sebesar 0,0092 atau 0,92\%. Selisih mutlak variabel sosialisasi keuangan dan kecerdasan intelektual memiliki nilai correlations partial sebesar 0,242 . Nilai tersebut kemudian dikuadratkan $\left(0,242^{2}\right)=0,0585$ dan dipersentasekan $(0,0585 \times 100 \%)=5,85 \%$. Secara parsial, interaksi variabel sosialisasi keuangan dengan kecerdasan intelektual mempengaruhi literasi keuangan syariah sebesar 0,0585 atau 5,85\%.

\section{Pengaruh Religiusitas terhadap Literasi Keuangan Syariah}

Berdasarkan hasil uji hipotesis, $\mathrm{Ha}_{1}$ yang menyatakan bahwa "Religiusitas berpengaruh positif dan signifikan terhadap literasi keuangan syariah" dinyatakan diterima. Hal ini dibuktikan dengan hasil uji signifikansi parsial (uji t) variabel religiusitas dengan nilai signifikansi $0,000<0,05$ dan nilai koefisien regresi sebesar 3,260. Adapun kontribusi secara parsial variabel religiusitas terhadap literasi keuangan syariah yaitu sebesar $12,53 \%$.

Hasil analisis deskriptif variabel religiusitas menunjukkan bahwa rata-rata tingkat religiusitas mahasiswa Pendidikan Ekonomi se-Kota Semarang Angkatan 2016 berada dalam kategori sangat tinggi. Religiusitas dalam penelitian ini meliputi dimensi keyakinan, dimensi praktik agama, dimensi pengalaman, dimensi pengetahuan agama, dan dimensi pengamalan. Dimensi keyakinan, praktik agama, dan pengalaman termasuk dalam kategori sangat tinggi, sedangkan dimensi pengetahuan agama dan pengamalan termasuk dalam kategori tinggi. Hasil analisis deskriptif juga menunjukkan variabel literasi keuangan syariah berada dalam katogori tinggi. Dapat dimaknai bahwa tingginya tingkat religiusitas pada mahasiswa akan menghasilkan tingkat literasi keuangan syariah yang tinggi pula. 
Secara singkat jika dilihat dari indikator dimensi pengetahuan agama dan pengamalan yang berada pada kategori tinggi, maka akan membuat mahasiswa semakin meyakini bahwa sistem keuangan syariah sesuai dengan ajaran Islam, sehingga mereka akan meyakini dan mempelajari tentang keuangan syariah. Hal tersebut akan meningkatkan literasi keuangan syariah khususnya indikator pengetahuan, keyakinan, dan keterampilan. Indikator dimensi keyakinan, dimensi praktik agama, dan dimensi pengalaman yang berada dalam kategori sangat tinggi, akan membuat mahasiswa menyadari bahwa segala transaksi keuangan yang mereka lakukan selama di dunia akan dihisab di akhirat, sehingga mereka akan menerapkan sikap dan perilaku keuangan sesuai dengan sistem keuangan syariah.

Tingkat religiusitas yang tinggi akan memotivasi seseorang untuk mempelajari hal-hal yang berkaitan dengan ajaran Islam termasuk juga dalam hal keuangan. Islam memiliki sistem keuangan yang disebut dengan sistem keuangan syariah. Seseorang yang religius akan terdorong untuk meningkatkan pengetahuan dan keterampilan keuangan syariah karena merupkan hal yang dianjurkan oleh Allah. Tingkat religiusitas yang tinggi juga membuat seseorang lebih yakin terhadap lembaga dan produk keuangan syariah daripada lembaga dan produk keuangan konvensional karena terhindar dari kemungkinan adanya riba. Apabila seseorang sudah memiliki pengetahuan, keterampilan, dan keyakinan terhadap lembaga dan produk keuangan syariah, maka ia akan mampu mengambil keputusan keuangan yang sesuai dengan kebutuhannya di dunia dengan tetap mempertimbangkan pertanggungjawaban di akhirat. Hal tersebut akan membuat seseorang memiliki sikap dan perilaku keuangan yang sesuai syariat. Dengan demikian, semua indikator literasi keuangan syariah dapat terpenuhi dan ditingkatkan apabila ada dorongan dari dalam diri seseorang yaitu religiusitas.

Penelitian ini berhasil mengkonfirmasi teori kognitif sosial (Bandura, 1986) yang menyatakan bahwa sebagian besar perilaku manusia adalah self-regulated behavior (perilaku yang diatur sendiri). Selain itu, Bandura juga percaya bahwa penguatan instrinsik yang datang dari evaluasi diri lebih berpengaruh daripada penguatan ekstrinsik yang diberikan oleh orang lain. Religiusitas dalam hal ini merupakan faktor internal atau bagian dari self-regulated behavior yang keberadaannya dapat mendorong seseorang untuk meningkatkan literasi keuangan syariah.

Hasil penelitian ini sejalan dengan penelitian yang dilakukan oleh Rahim et al., (2016) yang menemukan bahwa religiusitas berpengaruh positif dan signifikan terhadap literasi keuangan syariah pada mahasiswa Keuangan dan Perbankan Islam Universiti Utara Malaysia. Penelitian ini juga diperkuat oleh penelitian Meiati (2019) dengan hasil religiusitas berpengaruh positif dan signifikan terhadap literasi keuangan syariah karyawan perbankan syariah di Purwokerto.

\section{Pengaruh Pendidikan Keluarga terhadap Literasi Keuangan Syariah}

Hasil pengujian hipotesis menunjukkan bahwa $\mathrm{Ha}_{2}$ yang menyatakan "Pendidikan Keluarga berpengaruh positif dan signifikan terhadap literasi keuangan syariah" dinyatakan ditolak. Hal ini berdasarkan hasil uji signifikansi parsial (uji t) variabel pendidikan keluarga dengan nilai signifikansi $0,000>0,206$. Dapat diartikan bahwa pendidikan keluarga tidak berpengaruh terhadap literasi keuangan syariah.

Hasil analisis deskriptif menunjukkan bahwa rata-rata variabel pendidikan keluarga mahasiswa Pendidikan Ekonomi se-Kota Semarang Angkatan 2016 berada dalam kategori baik. Secara teori kognitif sosial (Bandura, 1986) seharusnya individu yang mengamati dan mendapatkan pengetahuan keuangan syariah melalui model hidup yang penelitian ini adalah keluarga atau orang tua, maka tingkat literasi keuangan syariah yang dimiliki akan meningkat karena sudah mempunyai bekal pengetahuan keuangan syariah dari keluarga. Hal ini menunjukkan bahwa meskipun pendidikan 
keluarga yang didapatkan oleh mahasiswa berada dalam kategori baik, akan tetapi tidak mampu berpengaruh terhadap tingkat literasi keuangan syariah pada mahasiswa.

Hal tersebut terjadi karena indikator latar belakang orang tua tidak berkaitan dengan keuangan syariah, sehingga orang tua tidak dapat mengajarkan tentang keuangan syariah dan pada akhirnya pendidikan keluarga tidak memberikan pengaruh apapun pada literasi keuangan syariah mahasiswa. Variabel pendidikan keluarga diukur melalui enam indikator. Dua indikator berada dalam kategori baik yaitu cara orang tua mendidik dan relasi antar anggota keluarga. Tiga indikator berada dalam kategori cukup baik yaitu suasana rumah, keadaan ekonomi keluarga, dan sikap perhatian orang tua, sedangkan indikator latar belakang orang tua berada pada kategori buruk. Indikator latar belakang orang tua berkaitan dengan pendidikan, pekerjaan, dan penggunaan produk keuangan syariah oleh orang tua. Buruknya indikator latar belakang orang tua ini menjadi penyebab tidak berpengaruhnya pendidikan keluarga terhadap literasi keuangan syariah.

Berdasarkan data identitas responden yang berkaitan dengan item pengukuran indikator latar belakang orang tua dapat diketahui data pendidikan dan pekerjaan orang tua responden. Data pendidikan orang tua responden menunjukkan rata-rata pendidikan ayah yaitu SMA/sederajat dengan jumlah $40,2 \%$ dan rata-rata pendidikan ibu yaitu SD/sederajat dengan jumlah 36,8\%. Tingkat pendidikan orang tua yang hanya lulusan SD/sederajat dan SMA/sederajat tentu saja belum mampu memberikan pengetahuan mengenai keuangan syariah karena di tingkat pendidikan tersebut belum diajarkan mengenai keuangan syariah. Selain itu, dilihat dari data pekerjaan rata-rata pekerjaan ayah adalah wirausaha dengan jumlah $31,4 \%$ dan rata-rata pekerjaan ibu adalah ibu rumah tangga atau tidak bekerja sebesar 53,9\%. Pekerjaan tersebut juga tidak berkaitan langsung dengan lembaga keuangan syariah sehingga peluang mahasiswa untuk memperoleh informasi keuangan syariah melalui pekerjaan orang tua sangatlah minim.

Berdasarkan skor item pernyataan keluarga menggunakan produk keuangan syariah, hanya sebanyak 15 mahasiswa yang menjawab sangat setuju dan 52 mahasiswa yang menjawab setuju. Total mahasiswa yang yakin bahwa keluarganya menggunakan produk keuangan syariah hanya sebanyak 67 mahasiswa, artinya tidak mencapai setengah dari jumlah sampel penelitian. Jika keluarga mahasiswa terutama orang tua mereka tidak menggunakan produk keuangan syariah, maka mereka tidak akan memperoleh informasi mengenai produk keuangan syariah yang bisa dibagikan kepada anaknya. Selain itu, ketika orang tua tidak menggunakan produk keuangan syariah, maka kemungkinan besar mahasiswa juga tidak akan menggunakan produk keuangan syariah. Hal ini dibuktikan dengan identitas responden yang menunjukkan bahwa 91,2\% mahasiswa tidak memiliki produk keuangan syariah. Latar belakang keluarga yang buruk menyebabkan pendidikan keluarga tidak mampu mempengaruhi literasi keuangan syariah mahasiswa Pendidikan Ekonomi se-Kota Semarang.

Hasil penelitian ini sejalan dengan penelitian Lutfi (2018) yang menemukan bahwa pendidikan keluarga tidak berpengaruh terhadap literasi keuangan syariah pada mahasiswa Perbankan Syariah Fakultas Ekonomi dan Bisnis Islam IAIN Surakarta. Menurut penelitian Lutfi (2018), tidak berpengaruhnya pendidikan keluarga terhadap literasi keuangan syariah disebabkan karena dalam keluarga seseorang tidak mendapatkan teori tentang keuangan yang sesuai dengan syariat Islam. Lebih lanjut ia menyebutkan bahwa besar kemungkinan anggota keluarga seperti orang tua hanya memberikan uang kepada anaknya tanpa memberikan arahan bahwa penggunaan uang tersebut juga akan dipertanggungjawabkan di akhirat. Hal tersebut menyebabkan mahasiswa berpikir bahwa tanpa memiliki literasi keuangan syariah mereka akan tetap bisa mengelola dan menggunakan keuangan dengan baik. 


\section{Pengaruh Sosialisasi Keuangan terhadap Literasi Keuangan Syariah}

Berdasarkan hasil uji hipotesis, $\mathrm{Ha}_{3}$ yang menyatakan bahwa "Sosialisasi keuangan berpengaruh positif dan signifikan terhadap literasi keuangan syariah" dinyatakan diterima. Hal ini berdasarkan hasil uji signifikansi parsial (uji t) variabel sosialisasi keuangan dengan nilai signifikansi $0,000<0,05$ dan nilai koefisien regresi sebesar 3,602. Nilai koefisien regresi tersebut berarti bahwa setiap peningkatan variabel sosialisasi keuangan sebesar satu satuan akan meningkatkan literasi keuangan syariah sebesar 3,602. Adapun kontribusi secara parsial variabel religiusitas terhadap literasi keuangan syariah yaitu sebesar $13,10 \%$.

Hasil analisis deskriptif variabel sosialisasi keuangan menunjukkan bahwa rata-rata variabel sosialisasi keuangan mahasiswa Pendidikan Ekonomi se-Kota Semarang Angkatan 2016 berada dalam kategori tinggi. Hal ini dapat dimaknai bahwa sosialisasi keuangan sudah dilakukan secara maksimal oleh mahasiswa Pendidikan Ekonomi se-Kota Semarang. Sosialisasi keuangan dalam penelitian ini diukur dengan menggunakan dua indikator yaitu teman sebaya dan media.

Teman sebaya sebagai indikator pertama dalam mengukur variabel sosialisasi keuangan memiliki rata-rata yang berada dalam kategori cukup. Hal ini menandakan bahwa mahasiswa Pendidikan Ekonomi se-Kota Semarang sudah menjadikan teman sebaya sebagai agen sosialisasi yang dapat memberikan informasi mengenai keuangan syariah, tetapi belum optimal. Berdasarkan keterangan identitas responden, hanya 3,4\% mahasiswa yang merupakan anggota kajian/BSO ekonomi syariah di kampus, sehingga terbukti bahwa mahasiswa Pendidikan Ekonomi se-Kota Semarang belum mampu mengoptimalkan peran teman sebaya untuk meningkatkan literasi keuangan syariah. Sosialisasi keuangan yang dapat dilakukan dengan teman sebaya yaitu berdikusi tentang informasi keuangan syariah atau paling tidak berdiskusi tentang tugas mata kuliah ekonomi syariah. Kegiatan sosialisasi keuangan lain yang dapat dilakukan dengan teman sebaya yaitu mengikuti kajian atau seminar keuangan syariah dan menjadi anggota dalam Badan Semi Otonom (BSO) atau Unit Kegiatan Mahasiswa (UKM) yang berkaitan dengan keuangan syariah. Semakin banyak kegiatan sosialisasi keuangan yang diperoleh dan dilakukan dengan teman sebaya maka akan semakin optimal keberadaan teman sebaya dalam meningkatkan literasi keuangan syariah.

Indikator lain yang digunakan untuk mengukur variabel sosialisasi keuangan adalah media. Indikator media memiliki nilai rata-rata yang berada dalam kategori tinggi. Hal ini menunjukkan bahwa mahasiswa Pendidikan Ekonomi se-Kota Semarang lebih mengoptimalkan sosialisasi keuangan melalui media daripada teman sebaya. Media yang dimaksud dalam penelitian ini yaitu media cetak dan media online. Media cetak yang berkaitan dengan keuangan syariah sangat jarang dimiliki oleh mahasiswa kecuali mata kuliah yang berkaitan mewajibkan memiliki buku tentang keuangan syariah. Hal tersebut tidak menjadi kendala bagi mahasiswa untuk memperoleh informasi keuangan syariah karena sudah ada media online. Di era milenial saat ini, setiap mahasiswa memiliki dan menggunakan gawai setiap hari. Gawai menjadikan mahasiswa lebih mudah untuk mengakses sumber belajar keuangan syariah secara online seperti mengikuti akun media sosial lembaga keuangan syariah, membaca berita atau penelitian keuangan syariah, dan menonton tayangan edukasi keuangan syariah. Keberadaan media online akan sangat membantu mahasiswa dalam memperoleh informasi keuangan syariah khususnya yang berkaitan dengan indikator pengetahuan dan keterampilan keuangan syariah. Informasi keuangan syariah yand didapat melalui media online akan sangat membantu mahasiswa dalam membuat keputusan pemilihan produk keuangan syariah yang sesuai dengan kebutuhan, sehingga mampu mendorong indikator perilaku keuangan syariah.

Hasil penelitian ini sesuai teori kognitif sosial (Bandura, 1986) yang menjelaskan bahwa salah satu faktor yang memainkan peran penting dalam pembelajaran adalah faktor sosial atau lingkungan. (Bandura, 1986) juga menyatakan bahwa sebagian besar pembelajaran manusia terjadi melalui 
pengamatan (vicarious learning). Sosialisasi keuangan merupakan bagian dari faktor lingkungan dan termasuk dalam sumber belajar model hidup dan media. Model hidup dalam variabel sosialisasi keuangan dicerminkan melalui indikator teman sebaya. Penelitian ini berhasil membuktikan bahwa faktor sosial atau lingkungan yaitu sosialisasi keuangan berperan penting dalam meningkatkan literasi keuangan syariah mahasiswa Pendidikan Ekonomi se-Kota Semarang.

Penelitian ini sejalan dengan penelitian yang dilakukan oleh Dewanty \& Isbanah (2018) dengan hasil sosialisasi keuangan berpengaruh positif dan diperkuat oleh penelitian Wibowo (2018) yang menemukan bahwa sosialisasi keuangan berpengaruh positif dan signifikan terhadap literasi keuangan syariah siswa Madrasah Aliyah Negeri (MAN) se-Kota Semarang.

\section{Kecerdasan Intelektual Memperkuat Pengaruh Religiusitas terhadap Literasi Keuangan Syariah}

$\mathrm{Ha}_{4}$ dalam penelitian ini yaitu "Kecerdasan intelektual memperkuat pengaruh religiusitas terhadap literasi keuangan syariah". Berdasarkan hasil penelitian, $\mathrm{Ha}_{4}$ dinyatakan ditolak. Hal ini ditunjukkan oleh hasil regresi uji-t yang menghasilkan nilai signifikansi $0,001<0,05$ dan nilai koefisien regresi sebesar -2,910. Nilai koefisien regresi bertanda negatif yang berarti bahwa kecerdasan intelektual tidak mampu memperkuat pengaruh religiusitas terhadap literasi keuangan syariah.

Berdasarkan hasil analisis deskriptif rata-rata kecerdasan intelektual mahasiswa Pendidikan Ekonomi se-Kota Semarang Angkatan 2016 berada dalam kategori tinggi, begitu juga dengan variabel religiusitas yang berada pada kategori sangat tinggi. Hal ini dapat dimaknai bahwa mahasiswa Pendidikan Ekonomi se-Kota Semarang memiliki kecerdasan intelektual yang seharusnya sangat mendukung untuk memperkuat pengaruh religiusitas terhadap literasi keuangan syariah. Sejalan dengan teori kognitif sosial (Bandura, 1986), kecerdasan intelektual dan religiusitas berperan sebagai aspek kognitif sekaligus sebagai self-regulated behavior (perilaku yang diatur sendiri). Ketika kecerdasan intelektual tinggi, seharusnya kemampuan mahasiswa untuk memahami dan menerapkan pengetahuan keuangan syariah yang diajarkan oleh dogma dari religiusitas juga tinggi, sehingga mampu memperkuat pengaruh religiusitas terhadap literasi keuangan syariah.

Kecerdasan intelektual dalam penelitian ini diukur dengan menggunakan lima indikator yaitu kemahiran berhitung, pemahaman verbal, pemahaman visual, kemampuan memecahkan masalah, dan kemampuan ingatan. Kelima indikator tersebut berada pada kategori tinggi kecuali, indikator kemahiran berhitung. Dapat disimpulkan bahwa indikator yang digunakan untuk mengukur kecerdasan intelektual hanya menyentuh ranah yang mendukung indikator pengetahuan keuangan syariah saja, sedangkan literasi keuangan syariah cakupannya lebih luas dan tidak hanya pada aspek pengetahuan saja.

Tingkat kecerdasan intelektual yang tinggi mampu membuat mahasiswa memahami materi ekonomi syariah dengan baik sehingga pengetahuan keuangan syariah mereka akan baik pula. Hal ini terbukti dari data identitas responden yang menunjukkan bahwa 49,5\% mahasiswa mendapatkan nilai A pada mata kuliah ekonomi syariah dan tidak ada yang mendapatkan nilai dibawah standar. Ketika mahasiswa merasa bahwa pengetahuan keuangan syariah tersebut sudah cukup, maka mereka tidak akan memperdalam indikator lain dari literasi keungan syariah. Hal ini akan menyebabkan tingkat literasi keuangan syariah menurun karena mahasiswa hanya akan memiliki indikator pengetahuan saja, tetapi ridak memiliki indikator keterampilan, keyakinan, sikap, dan perilaku keuangan syariah.

Indikator pengukuran kecerdasan intelektual yang memiliki skor terendah adalah kemahiran berhitung yang berada pada kategori cukup. Mahasiswa dengan tingkat religiusitas yang tinggi tentunya akan meyakini dan memahami bahwa riba merupakan hal yang diharamkan dalam Islam, sehingga ia akan mempelajari lebih lanjut tentang riba. Mahasiswa Pendidikan Ekonomi se-Kota Semarang sudah mendapatkan materi tentang riba melalui mata kuliah ekonomi syariah. Materi 
tersebut menjelaskan bahwa sistem bunga termasuk dalam unsur riba, sehingga lebih disarankan menggunakan sistem bagi hasil. Perbedaan sistem bunga dengan sistem bagi hasil dapat dilihat dari cara perhitungan keuntungan. Indikator kecerdasan intelektual dalam kemahiran berhitung yang hanya berada pada kategori cukup akan membuat mahasiswa belum sepenuhnya mampu melakukan perhitungan bagi hasil, apalagi setiap akad dalam keuangan syariah memiliki perhitungan yang berbeda-beda. Hal inilah akan menyebabkan literasi keuangan syariah indikator keterampilan menjadi lemah.

Tingkat religiusitas mahasiswa Pendidikan Ekonomi se-Kota Semarang berada pada kategori sangat tinggi membuat mereka memiliki dorongan lebih untuk mempelajari dan menerapkan sistem keuangan syariah. Ketika mereka memiliki kecerdasan intelektual yang juga tinggi, maka dorongan untuk mempelajari dan menerapkan sistem keuangan syariah menjadi semakin menurun. Hal ini dikarenakan kecerdasan intelektual membuat seseorang cenderung mengandalkan logika dan menganalisis segala sesuatu yang akan dilakukan, termasuk dogma yang diterima dari nilai-nilai religius. Dogma tentang keuangan syariah yang didapatkan karena tingkat religiusitas yang tinggi tetap saja tidak langsung dilaksanakan karena dianalisis terlebih dahulu sesuai logika berpikir orang tersebut. Orang yang religius akan menjadikan agama sebagai pedoman dalam berbagai aspek kehidupan termasuk dalam hal keuangan, sedangkan orang yang cerdas akan menalar bahwa agama hanya mengatur ibadah wajib saja dan tidak sampai pada aspek keuangan. Hal tersebut menjadikan orang yang cerdas merasa bahwa literasi keuangan syariah bukan hal yang termasuk dalam ibadah wajib, sehingga tidak harus dimiliki dan diterapkan, sehingga indikator sikap dan perilaku keuangan syariah akan menurun. Keberadaan kecerdasan intelektual yang tinggi dapat menyebabkan indikator keterampilan, sikap, dan perilaku keuangan syariah menjadi menurun, sehingga secara keseluruhan literasi keuangan syariah akan ikut menurun. Dengan demikian kecerdasan intelektual tidak mampu memperkuat pengaruh religiusitas terhadap literasi keuangan syariah.

\section{Kecerdasan Intelektual Memperkuat Pengaruh Pendidikan Keluarga terhadap Literasi Keuangan Syariah}

Berdasarkan hasil penelitian, $\mathrm{Ha}_{5}$ dinyatakan ditolak. Hal ini ditunjukkan oleh hasil regresi uji-t yang menghasilkan nilai signifikansi $0,176>0,05$. Dapat diartikan bahwa variabel kecerdasan intelektual tidak mampu mempekuat pengaruh pendidikan keluarga terhadap literasi keuangan syariah mahasiswa Pendidikan Ekonomi se-Kota Semarang.

Hasil analisis deskriptif menunjukkan bahwa rata-rata variabel pendidikan keluarga mahasiswa Pendidikan Ekonomi se-Kota Semarang Angkatan 2016 berada dalam kategori baik dan kecerdasan intelektual mereka bereda dalam katergori tinggi. Secara teori kognitif sosial (Bandura, 1986) seharusnya kecerdasan intelektual mampu memperkuat pengaruh pendidikan keluarga terhadap literasi keuangan syariah. Keluarga merupakan faktor lingkungan yang dapat memberikan bekal pengetahuan keuangan syariah kepada mahasiswa, sedangkan kecerdasan intelektual merupakan faktor kognitif yang dapat membantu mahasiswa dalam memahami pengetahuan keuangan syariah yang didapatkan.

Hal yang diduga membuat kecerdasan intelektual tidak memperkuat pengaruh pendidikan keluarga terhadap literasi keuangan syariah adalah karena pendidikan keluarga belum memberikan pengetahuan keuangan syariah yang optimal kepada mahasiswa. Hal ini dapat dilihat dari hasil uji regresi $\mathrm{Ha}_{2}$ yang menyatakan bahwa pendidikan keluarga tidak berpengaruh terhadap literasi keuangan syariah. Tingkat kecerdasan intelektual yang tinggi menjadi tidak berpengaruh dalam mempertahankan pengetahuan keuangan syariah mahasiswa karena dalam pendidikan keluarga mahasiswa tidak memperoleh pengetahuan keuangan syariah. Secara logis mahasiswa akan berpikir bahwa ketika orang tua atau keluarga mereka mampu mengelola keuangan dengan baik tanpa melibatkan pengetahuan keuangan syariah, maka literasi keuangan syariah menjadi tidak terlalu dibutuhkan bagi mereka. 
Mahasiswa dengan tingkat kecerdasan intelektual yang tinggi juga akan mempunyai kemampuan menyelesaikan masalah dengan baik termasuk juga masalah keuangan. Hal tersebut akan membuat mahasiswa merasa bahwa mereka mampu membuat keputusan keuangan yang tepat dan logis tanpa harus memiliki literasi keuangan syariah terlebih dahulu. Selain itu, kecerdasan intelektual yang tinggi membuat mahasiswa Pendidikan Ekonomi se-Kota Semarang Angkatan 2016 mampu memahami mata kuliah ekonomi syariah dengan baik. Hal ini dibuktikan dengan nilai mata kuliah ekonomi syariah mereka yang semuanya berada pada kategegori di atas standar. Mahasiswa tidak lagi memiliki rasa ketertarikan untuk mendalami tentang keuangan syariah karena merasa pengetahuan keuangan syariah yang mereka dapatkan melalui mata kuliah ekonomi syariah saja sudah cukup. Dengan demikian, tingkat literasi keuangan syariah mereka tidak akan bertambah.

\section{Kecerdasan Intelektual Memperkuat Pengaruh Religiusitas terhadap Literasi Keuangan Syariah}

$\mathrm{Ha}_{6}$ dalam penelitian ini yaitu "Kecerdasan intelektual memperkuat pengaruh sosialisasi keuangan terhadap literasi keuangan syariah". Berdasarkan hasil penelitian, $\mathrm{Ha}_{5}$ dinyatakan diterima. Hal ini ditunjukkan oleh hasil regresi uji-t yang menghasilkan nilai signifikansi 0,001<0,05 dan nilai koefisien regresi sebesar 3,318. Nilai koefisien regresi bertanda positif yang berarti bahwa kecerdasan intelektual memperkuat pengaruh sosialisasi keuangan terhadap literasi keuangan syariah. Hal ini menjelaskan bahwa semakin tinggi kecerdasan intelektual, maka semakin tinggi koefisien pengaruh sosialisasi keuangan terhadap literasi keuangan syariah.

Berdasarkan hasil analisis deskriptif rata-rata kecerdasan intelektual mahasiswa Pendidikan Ekonomi se-Kota Semarang Angkatan 2016 berada dalam kategori tinggi, begitu juga dengan variabel sosialisasi keuangan yang berada pada kategori tinggi. Hal ini dapat dimaknai bahwa mahasiswa Pendidikan Ekonomi se-Kota Semarang memiliki kecerdasan intelektual yang sangat mendukung untuk memperkuat pengaruh sosialisasi keuangan terhadap literasi keuangan syariah. Hasil hipotesis ini sejalan dengan teori kognitif sosial (Bandura, 1986) yang menjelaskan bahwa proses belajar dan perilaku seseorang dipengaruhi oleh faktor lingkungan dan faktori kognitif. Sosialisasi keuangan merupakan faktor lingkungan, sedangkan kecerdasan intelektual merupakan faktor kognitif. Ketika seseorang memiliki sosialisasi keuangan yang tinggi, diperkuat dengan dengan kecerdasan intelektual yang tinggi, maka literasi keuangan syariahnya akan semakin tinggi.

Kecerdasan intelektual dalam penelitian ini diukur dengan menggunakan lima indikator yaitu kemahiran berhitung, pemahaman verbal, pemahaman visual, kemampuan memecahkan masalah, dan kemampuan ingatan. Kelima indikator tersebut berada pada kategori tinggi kecuali, indikator kemahiran berhitung. Kemampuan pemahaman verbal dan pemahaman visual yang tinggi akan membuat mahasiswa lebih mudah untuk memahami informasi keuangan syariah yang diperoleh melalui sosialisasi keuangan. Pemahaman keuangan syariah tersebut juga akan bertahan lama karena didukung oleh kemampuan ingatan mahasiswa yang juga berada dalam katergori tinggi. Indikator kemampuan memecahkan masalah yang juga berada dalam kategori tinggi, akan menjadikan mahasiswa lebih mudah mengatasi masalah keuangan dengan tetap melibatkan pemahaman keuangan syariah yang sudah diperoleh. Penjelasan hasil penelitian tersebut menunjukkan bahwa keberadaan variabel kecerdasan intelektual terbukti mampu memperkuat pengaruh sosialisasi keuangan terhadap literasi keuangan syariah.

\section{SIMPULAN}

Simpulan dari penelitian ini adalah religiusitas berpengaruh positif dan signifikan terhadap literasi keuangan syariah mahasiswa Jurusan Pendidikan Ekonomi se-Kota Semarang Angkatan 2016. Pendidikan keluarga tidak berpengaruh terhadap terhadap literasi keuangan syariah mahasiswa 
Jurusan Pendidikan Ekonomi se-Kota Semarang Angkatan 2016. Sosialisasi keuangan pengaruh positif dan signifikan terhadap literasi keuangan syariah mahasiswa Jurusan Pendidikan Ekonomi se-Kota Semarang Angkatan 2016. Kecerdasan intelektual tidak mampu memperkuat pengaruh religiusitas terhadap literasi keuangan syariah mahasiswa Jurusan Pendidikan Ekonomi se-Kota Semarang Angkatan 2016. Kecerdasan intelektual tidak mampu memperkuat pengaruh pendidikan keluarga terhadap literasi keuangan syariah mahasiswa Jurusan Pendidikan Ekonomi se-Kota Semarang Angkatan 2016. Kecerdasan intelektual mampu memperkuat pengaruh sosialisasi keuangan terhadap literasi keuangan syariah mahasiswa Jurusan Pendidikan Ekonomi se-Kota Semarang Angkatan 2016.

\section{DAFTAR PUSTAKA}

Ahmad Sabri. (2005). Strategi Belajar Mengajar: Microteaching. Quantum Teaching.

Anastasi, A., \& Urbina, S. (2013). Tes Psikologi Edisi Ketujuh (7th ed., Issue 2006). PT. Indeks.

Anastasi, A., \& Urbina, S. (2007). Tes Psikologi Edisi Ketujuh. PT. Indeks.

Anita , Prof . Dr. Said Mohammad, M.A, P. D. A. H. (2014). PENGARUH DESENTRALISASI FISKAL TERHADAP PERTUMBUHAN EKONOMI DI PROVINSI ACEH. Jurnal Ilmu Ekonomi, 2(3), 21-29.

Bandura, A. (1986). Social Foundations of Thought and Action. Prentice Hall.

Dewanty, N., \& Isbanah, Y. (2018). Determinants of the Financial Literacy: Case Study on Career Woman in Indonesia. 17(2), 285-296.

Djamaludin Ancok, F. N. S. (2015). Psikologi Islami. Pustaka Pelajar.

Eliza, A. (2018). LITERASI KEUANGAN ISLAM DAN FAKTOR-FAKTOR YANG MEMPENGARUHINYA (STUDI PADA DOSEN DAN KARYAWAN FAKULTAS EKONOMI DAN BISNIS ISLAM UIN RADEN INTAN LAMPUNG).

FITRIANI, A. ST. (2017). PENGARUH PENDIDIKAN KEUANGAN DI KELUARGA, TEMAN SEBAYA DAN PEMBELAJARAN DI PERGURUAN TINGGI TERHADAP LITERASI KEUANGAN MAHASISWA PADA PERGURUAN TINGGI NEGERI DI MAKASSAR. UNIVERSITAS ISLAM NEGERI ALAUDDIN MAKASSAR.

HERD, P., HOLDEN, K., \& SU, Y. T. (2012). The Links between Early-Life Cognition and Schooling and Late-Life Financial Knowledge. 46(3), 411-435. https://doi.org/10.1111/j.1745-6606.2012.01235.x

Islamic Corporation For The Development Of The Private Sector (ICD). (2019). Islamic Finance Development Report-2019: Shifting Dynamics. In Icd-Rfinitif.

Karodoyo, Hadi, S., \& Nurkhin, A. (2018). PROGRAM PENINGKATAN LITERASI KEUANGAN SYARIAH BAGI GURU TAMAN PENDIDIKAN ALQURAN ( TPQ) DI KOTA SEMARANG. 24(2), 655-660.

Lutfi, A. A. (2018). PENGARUH PENDIDIKAN PENGELOLAAN KEUANGAN DI KELUARGA DAN PEMBELAJARAN DI PERGURUAN TINGGI TERHADAP LITERASI KEUANGAN SYARIAH MAHASISWA STUDI PADA MAHASISWA JURUSAN PERBANKAN SYARIAH FAKULTAS EKONOMI DAN BISNIS ISLAM IAIN SURAKARTA TAHUN ANGKATAN 2015-2016. Institut Agama Islam Negeri Surakarta.

Maria, L. (2019). PENGARUH PENDIDIKAN, AGEN SOSIALISASI, DAN MONEY ATTITUDE TERHADAP LITERASI KEUANGAN DAN DAMPAKNYA PADA INKLUSI KEUANGAN UMKM DI BANDUNG. 146. 
Meiati, E., \& Jayanto, P. Y. (2019). Pengaruh Religiusitas, Lingkungan Sosial, Pengalaman Kerja, dan Tingkat Pendidikan terhadap Literasi Keuangan Syariah Karyawan Perbankan Syariah di Purwokerto.

Nurrahman, A. (2019). IFDI: Peringkat Industri Keuangan Syariah Indonesia Meroket Ke Peringkat Empat. https://knks.go.id/berita/186/ifdi-peringkat-industri-keuangan-syariah-indonesia-meroket-keperingkat-empat?category $=1$

Peraturan Presiden Tentang Komite Nasional Keuangan Syariah, Pub. L. No. Nomor 91 Tahun 2016 (2016).

Pujaningrum, S., \& Nurkhin, A. (2018). PENGARUH KEBIASAAN PENGELUARAN DAN KEPUASAN FINANSIAL TERHADAP LITERASI KEUANGAN SYARIAH DENGAN RELIGIUSITAS SEBAGAI VARIABEL MODERASI. In Economic Education Analysis Journal. Universitas Negeri Semarang.

Rahim, S. H. A., Rashid, R. A., \& Hamed, A. B. (2016). Factor Analysis of Islamic Financial Literacy and Its Determinants: A Pilot Study. International Soft Science Conference, 413-418.

Santrock, J. W. (2009). Psikologi Pendidikan Edisi 3. (R. Oktafiani, Ed.) (3rd ed.). Salemba Humanika.

Schunk, D. H. (2012). Learning Theories an Educational Perspective Edisi Enam. (E. Setyowati, Ed.) (Enam). Pustaka Pelajar.

Schunk, Dale H. (2012). LEARNING THEORIES An Educational Perspective. In E. Setyowati (Ed.), Pustaka Pelajar (keenam). Pustaka Pelajar.

Setiawati, M. (2016). PENGARUH KECERDASAN, PENGETAHUAN EKONOMI DAN PERILAKU KONSUMTIF TERHADAP LITERASI KEUANGAN PADA SISWA KELAS XI IPS SMA NEGERI SEKOTA MADIUN. UNIVERSITAS SEBELAS MARET.

Slameto. (2010). Belajar dari Faktor-Faktor yang Mempengaruhinya. Rineka Cipta.

Wibowo, Y. R., \& Nurkhin, A. (2018). PERAN RELIGIUSITAS DALAM MEMEDIASI PENDIDIKAN KELUARGA DAN SOSIALISASI KEUANGAN TERHADAP LITERASI KEUANGAN SYARIAH. In Economic Education Analysis Journal. Universitas Negeri Semarang.

Widarni, W., \& Chairil, A. (2019). Pengaruh Gender, Agen Sosialisasi Keuangan, Pengalaman Keuangan, dan Sikap pada Uang Terhadap Finansial Literasi Mahasiswa Universitas Bengkulu. Universitas Bengkulu. 